\title{
SHARENTING BAĞLAMINDA SOSYAL MEDYADA ÇOCUK İMAJININ İNŞASI
}

\author{
(Construction Of Child's Image In Social Media In The Context Of Sharenting)
}

\section{Hakan YÜKSEL ${ }^{1}$}

\author{
Araştırma Makalesi \\ Makale Geliş Tarihi: 08.10.2021 \\ Makale Kabul Tarihi: 02.12.2021
}

DOI: 10.53507/akademikdusunce.1006473

\section{ÖZ}

Bilgi ve içerik paylaşımı, sosyal medyada her geçen gün artarak devam eden bir eylem niteliğindedir. $\mathrm{Bu}$ eylemsel süreç her yaş grubundan bireyleri sosyal medya ortamlarına bağımlı duruma getirdiği gibi aynı zamanda sınırsız düzeyde paylaşımların önünü açmaktadır. Ebeveynlerin çocuklarına ait görsel içerikleri kapsamlı ve detaylı olarak paylaşması da sosyal medyanın hareket alanı bağlamındadır ve bu durum mahremiyet sinırlarının kolayca aşıldığını göstermektedir. Nitekim sharenting olarak adlandırılan ve çocukları sosyal medya paylaşımlarının öznesi durumuna getiren bir sorunsal ortaya çıkmaktadır ve bu doğrultuda sosyal medya eksenli çocuk imaj1 kurgulanmaktadır. Yürütülen çalışmada ise inşa edilen çocuk imajına temas edilmektedir ve bu süreçte sharenting eyleminin gerek olumlu gerekse olumsuz yansımaları irdelenmektedir. Nitel araştırma yöntemlerinden olan doküman analizinden yararlanılarak da çalışma başlıkları açıklanmaktadır. Sonuç kısmında ise sharenting eyleminin sebebiyet verdiği psikolojik ve sosyolojik neticeler tartışılmaktadır.

Anahtar Kelimeler: Sharenting, Sosyal Medya, Çocuk Imajl.

\begin{abstract}
Sharing information and content is an action that continues to increase day by day on social media. This operational process not only makes individuals from all age groups dependent on social media, but also causes unlimited sharing. Parents' sharing of their children's visual content in detail is in the context of social media's field of action, and this shows that the limits of privacy are easily exceeded. As a matter of fact has arised a problem called sharenting and making children the subject of social media and in this direction, is constructed the image of the child in the context of social media. In this study, is touched the current child image on and in this process are examined both positive and negative reflections of the sharenting act. The study titles are explained by making use of document analysis, which is one of the qualitative research methods. In the conclusion part, the psychological and sociological consequences are discussed of the sharenting action.
\end{abstract}

Keywords: Sharenting, Social Media, Child Image

\footnotetext{
${ }^{1}$ Öğr. Gör. Dr. Kafkas Üniversitesi Sosyal Bilimler Meslek Yüksekokulu, hakanyuksel25@gmail.com, ORCID: 0000-0002-4560-6685.
} 


\section{Giriș}

Sosyal medyanın etkileşime açık yapısı ve kullanıcıları aktif duruma getiren pratikliği, yeni sosyal medya sayfalarının giderek artmasına ortam sağladığı gibi hedef kitlesini de bu eksende genişletmektedir. Bireyler yaşamlarına dair her anı bu platformlarda paylaşarak görsel içerikler aracılığıyla birbirlerinden haberdar olmaktadır ve böylece sosyal ağ toplumu olarak sanal bir hareket alanı oluşturulmaktadır. Ancak sosyal medyanın hızlı etkileşim sağlayan bu yönünün zararlı yansımaları da olabilmektedir ve nitekim sanal ortamlarda paylaşılan içerikler, farklı amaçlar güden kişi ve grupların eline geçebilmektedir. Siber saldırı gruplarından dolandırıcı çetelerine, istismarcı kişilerden art niyetli birçok yapılanmalara kadar risk boyutu geniş olan tehditlerle karşılaşılabilmektedir.

Ebeveynlerin çocuklarına dair resim ve videoları internet ortamında sıklıkla paylaşması durumunu yansıtan "Sharenting" eylemi de bu tehditlere müsait yapısıyla dikkat çekmektedir. Zira çocuk henüz doğmadan ultrason görüntüleriyle başlayan ve neredeyse resmi kimliği çıkarılmadan sosyal medya hesapları açılan bir yaklaşımın neticesi olan sharenting, çocuğa dair mahremiyet sınırlarını ihlal ettiği gibi, uzun vadede problem doğurabilecek sonuçlara da zemin hazırlamaktadır. Bilhassa herkese açık gönderilerin malzemesi olan ve ev, okul, tatil gibi hayatının her akışı sosyal medyaya sunulan çocuklar, ebeveynlerinin kontrolsüz hareketi bağlamında sanal bir hayat sürdürebilmektedir.

Çalışmanın merkezinde sharenting eylemi neticesinde çocukların ne gibi tehditlerle karşılaşabileceği üzerinde durulmaktadır. Zira artık ebeveyn rekabetinden maddi kazanç elde etme beklentisine, akran ve çevre baskısından paylaşım bağımlılığına kadar birçok faktör, çocukları sosyal medyada sıklıkla öne çıkaran bir anlayış doğurmaktadır. Küresel dünyanın da problemi olan ve son yıllarda bilimsel çalışmalarla temas edilen bu anlayış, bazı ülkelerde alınan hukuki önlemlerle en aza indirgenmeye çalışılmaktadır. Buna rağmen sosyal medya fenomenleri başta olmak üzere milyonlarca ebeveyn çocuklarının kişilik haklarını göz ardı ederek mahremiyetlerini açığa çıkarmaktadır.

Aynı zamanda sosyal medyada yeni bir çocuk imajı inşa eden ve böylece çocukların gerçek hayata entegre olmasını zorlaştırarak ayrı bir probleme sebebiyet veren sharenting eylemi, birçok uzmanlık alanının da odak noktası durumuna gelmektedir. Öyle ki bilim insanları, psikologlar, sosyal medya uzmanları ve avukatlar sharenting eyleminin somut çıktıları üzerinde durarak ebeveynleri uyarmaktadır. Her ne kadar masum bir düşünceyle çocuklarının yarı çıplak resimlerini herkese açık olarak paylaşan bir ebeveyn profili söz konusu 
olsa da bu görsellerin pedofili sitelerine düşme ihtimali mevcuttur ve söz konusu bu risk durumu açısından ebeveynler bilgilendirilmektedir. Benzer şekilde kimlik dolandırıcılığg ve reklam malzemesi olarak kullanma girişi gibi çeşitli problemler de anne ve babaların karşılaşabileceği faktörler olarak değerlendirilmektedir.

Nitekim çalışmada, sharenting eyleminin sosyal medyada inşa etmiş olduğu çocuk imajı ele alınmaktadır. Bu çerçeve bağlamında çalışmada veri toplama amacıyla kaynak araştırmasının yapıldığı nitel bir araştırma yöntemi olan doküman inceleme analizinden yararlanılmaktadır (Bowen, 2009). Netice olarak ise gerek literatür taramasıyla gerekse doküman inceleme analiziyle sharenting eyleminin yol açtığı ve yol açabileceği risk durumları öne çıkarılmaktadır.

\section{Sharenting Kavramı}

Sosyal medya ortamında cereyan eden sınırsız paylaşım etkileşiminin mahremiyet alanlarını geçmesiyle birlikte, aile içinde yaşanan birçok şey erişime açık duruma gelmiştir. Bu doğrultuda anne ve babaların sadece şahsi resimlerini ve arkadaş ortamlarındaki anılarını değil aynı zamanda çocuklarına ilişkin görsel ve videoları sosyal medya araçları üzerinden paylaşmasıyla, literatüre "sharenting" adı verilen yeni bir kavram yerleşmiştir. Gerek video platformları aracılığıyla paylaşılan ve çocukların gündelik yaşamındaki hareketlerini internet kullanıcılarına sunan gerekse Facebook ve Instagram gibi sosyal ağlar çerçevesinde resimlerle çocukların dünyasını açığa çıkaran sharenting eylemi, giderek yaygın düzeye ulaşmıştır.

Ebeveynlerin çocuklara dair detaylı bilgiler vermesi ve bu bilgileri sosyal ağlarla hem görselleştirip hem de videolu olarak paylaşması ise, mahremiyeti doğrudan ihlal eden bir sharenting faktörünü ortaya çıkarmıştır (Brosch, 2018: 78). Bununla birlikte, "paylaşmak" ve "ebeveynlik" kelimelerinin birleşmesiyle oluşan karma bir kavram niteliğindeki sharenting, mahremiyet ihlali bağlamında çocukların dünyasına ait her şeyi belgeleme ve yayınlama girişimi olarak değerlendirilmiştir. Sharenting; aynı zamanda çocukların ilk konuşması, ilk gülümsemesi ve ilk adımını atması gibi özel anlarını sosyal medyada yayınlayan bir ebeveyn paylaşım hareketidir (Sirapediva, 2021).

Öte yandan sharenting kavramı genel olarak sosyal medya ve yaygın telekomünikasyon kanallarına atıfta bulunmak için kullanılsa da doğum esnasından gençlik dönemine kadar çocukların tüm hareket ağını kapsayan bir nitelik taşımaktadır (Hsu, 2019). Collins Dictionary ise sharenting kavramını sosyal medyayı düzenli ve etkin kullanan ebeveynlerin bu yaklaşımı ile ilişkilendirmektedir ve dolayısıyla sosyal medya etkileşiminde yer alan ebeveynlerin 
çocuklarına ait birçok detaylı bilgiyi takipçileriyle paylaşması olarak öne çıkarmaktadır (Brosch, 2016: 228). Zira artık günümüz dünyasında çocuklar daha doğmadan internet ortamında yer almaktadır ve anne karnındaki puslu ultrason görüntüleri ebeveynleri tarafından sosyal medya platformlarına aktarılmaktadır (La France, 2016).

Çocuğun gizliliğini daha henüz doğmadan açığa çıkaran bu durum, adeta çocukların her sürecini sosyal medyada paylaşma gereği duyan bir ebeveyn modelinin neticesidir ve çocuğun meşru gizliliğinin ortadan kalkmasına sebebiyet vermektedir (Dursun, 2019). Söz konusu ebeveyn modeli farklı ailelerde ve farklı kültürlerde hem psikolojik hem de sosyolojik bağlamda değişkenlik gösterse de dijital çağda sosyal medyayı paylaşım aracı kılmaya devam etmektedir (Wagner ve Gasche, 2018). Nihayetinde sosyal medyadaki profil resimlerini çocuklarından oluşturan, Youtube paylaşımlarında çocuklarını videoların öznesi konumuna getiren ve Instagram hikayelerinde yine çocuklarını öne çıkarmaktan kendini alıkoyamayan bir ebeveyn kültürü yerleşmektedir.

Ayrıca çocukları üzerinden psikolojik tatmin noktasına ulaşan bir ebeveyn yaklaşımı mevcuttur ve sharenting eylemini giderek yaygın kılan bu yaklaşım, ebeveynlik vazifesinin yerine getirildiğinin göstergesi olarak sunulmaktadır. Nitekim çocukların yer aldığ 1 sosyal medya paylaşımları beğeni alan ve yorumlanan ebeveynler, adeta görevlerinin karşıllı̆ı olarak bu geri bildirimleri dikkate almaktadır (Keith, 2017). Öyle ki sosyal medya ebeveynlerin rekabet içerisine girdiği bir alan niteliğine bürünmektedir ve aileler tatil fotolarından kreş videolarına ve doğum günü paylaşımlarına kadar sharenting eylemini işlemektedir.

Sharenting eylemini tehlikeli boyuta getiren husus ise sosyal medyanın erişime açık bir platformlar bütünlüğü olmasıdır ve bu alanda ebeveynlerin de aralarında olduğu tüm kullanıcıların şahsi hesaplarında birçok kişiyi bulundurmasıdır. Bu kişiler hızlı takip akışı içerisinde her zaman tanıdıklardan oluşmadığı için ebeveynlerin yapmış olduğu her paylaşım yabancı kişilerin eline kolayca geçebilmektedir. Üstelik söz konusu paylaşımlarda konum bilgilendirmesi yapan, her aktivitesini paylaşan ve hatta gelecek planlarını belirten ebeveynler bilhassa çocuklarını tehlikeye atmaktadır (Çalış, 2020). Ebeveynlerin bu tehlikeyi göz önünde bulundurarak paylaşımlarda tüm detaylara dikkat etmesi oldukça mühimdir.

Sosyal medya fenomenleri de olası riskleri dikkate alarak paylaşım yapmalıdır. Ancak daha fazla takipçi elde etmek, daha fazla abone sayısına ulaşmak ve beğeni/yorum almak için çocukların kolayca öne çıkarıldığı bir ortam söz konusudur. Sorumluluk bilinciyle hareket edilmesi ve rızası dahi alınmadan paylaşımı yapılan çocukların en azından karşılaşılabilecek 
risklerden korunması gereklidir. Aksi durumda çocukların zihinsel, fiziksel ve duygusal sağlı̆̆ üzerinde ciddi tahribatlar oluşabilmektedir (Al Kurdi, 2021). Sosyal medyanın büyülü dünyasına kendini kaptıran çocukların gerçek hayatta çevresinden aynı ilgiyi alamaması ise ayrı bir problem olarak kalıcı etkiye neden olabilmektedir.

Ebeveynlerin toplumsal bir kuralmışçasına sosyal medyada sharenting eylemini hızla sürdürmesi ve çocukları üzerinde mevcut hayatlarının neşeli ve kederli anlarına temas etmesi, küresel bir harekete dönüşmektedir (Brosch, 2016: 229). Bu hareket akışında göz ardı edilen başlıca husus ise çocukların da bir birey olduğunun unutulmasıdır. Zira onlar da bağımsızdır ve mahremiyetlerine saygı duyulmalıdır (Cordeiro, 2021). Fakat sosyal medya bağımlılığı ebeveynleri bu farkındalıktan soyutlamaktadır ve çocukların paylaşım metasına dönüşmesinin önüne geçilememektedir. Sharenting neticesinde yaşanan problemli hadiseler ise yeterince dikkate alınmamaktadır.

Öyle ki ebeveynlerin paylaştığı görseller kolayca reklam malzemesi yapılabilmektedir ve böylece herhangi bir çocuğun resmi izinsizce çeşitli objeler üzerinde kullanılabilmektedir (Blum Ross ve Livingstone, 2017). Sosyal medyanın küresel bir platform olduğu dikkate alındığında, bu durum ebeveynlerin haberi bile olmadan farklı ülkelerde yaşanabilmektedir. Diğer taraftan kimlik hırsızlığına sebebiyet verecek paylaşımlar yapılması, çocuklar açısından uzun vadeli problemlere zemin hazırlamaktadır ve nitekim art niyetli kişilerin farklı amaçlarla kullanabileceği bir olanağa dönüşmektedir (Steinberg, 2017).

$\mathrm{Bu}$ çerçevede Bilgi Teknolojileri ve İletişim Kurumu tarafindan güncel olarak sunulan "Dijital Mahremiyet" adlı içerikte sharenting kavramı üzerinde durulmuştur ve ebeveynlerin karşılaşabileceği hususlara değinilmiştir (Güvenli Web, 2021):

- Dijital kimliğin öne çıkarılmasıyla çocuklar gerçek hayattan giderek soyutlanabilir ve birtakım problemler yaşayabilir.

- Paylaşılan içerikler çocukların gizliliğini olumsuz yönde etkileyebilir.

- Her anı paylaşılan çocuklar ilerleyen dönemde bu durumdan rahatsızlık duyabilir ve ailelerini sorgulayabilir.

- Çocukların mahremiyet faktörüne bakış açısı sharenting ile birlikte değişebilir.

- Görselleri ve videoları paylaşılan çocuklar, sosyal medyada istismarcıların hedefine yerleşebilir ve sanal ortamda kötü amaçlarla bu içerikler kullanılabilir.

\section{Sosyal Medyada Sharenting}

Bireylerin paylaşımlar üzerinden birbirinden haberdar olduğu bir alanı temsil etmesiyle ayrıca öne çıkan sosyal medya platformlarında, akran desteği açısından ebeveynler sanal 
içerikleri değerli görmektedir. Aynı zamanda sosyal medyanın etkin kullanımı anne ve babalar için önemli bir motivasyon kaynağı olarak kabul görmektedir (Morris, 2014) ve yapılan her paylaşım akran rekabetini beraberinde getirmektedir. Mahremiyetin, kişilik haklarına saygının ve olası tehlikelerin geri plana atıldığı ve yalnızca sosyal medyada daha fazla nasıl görünürlük elde edilebilir mantalitesinin ağır bastığı bir durum yaşanmaktadır.

Sosyal medyada sharenting eylemini sürdürülebilir kılan bu görünürlük durumu bazı yönleriyle olumlu etki de uyandırmaktadır. Örneğin, ebeveynlerin yapmış olduğu paylaşımlar yeni ebeveynler için deneyim oluşturabilir ve çocukların büyüme çağında uygulanacak yöntemleri destekleyebilir. Bununla birlikte sosyal medyanın ortak alanlarında topluluk adı altında buluşan ebeveynler istişareler neticesinde birlikte karar alabilir ve dolayısıyla birlikte hareket edebilir (Criscuolo, 2015). Fakat paylaşımlarda gizliliğin önüne yeterince geçilmediği takdirde, internet mecrasındaki kötü amaçlı odaklar masum bir fotoğraftan dahi çeşitli teknik dokunuşlarla çıkar elde edebilir.

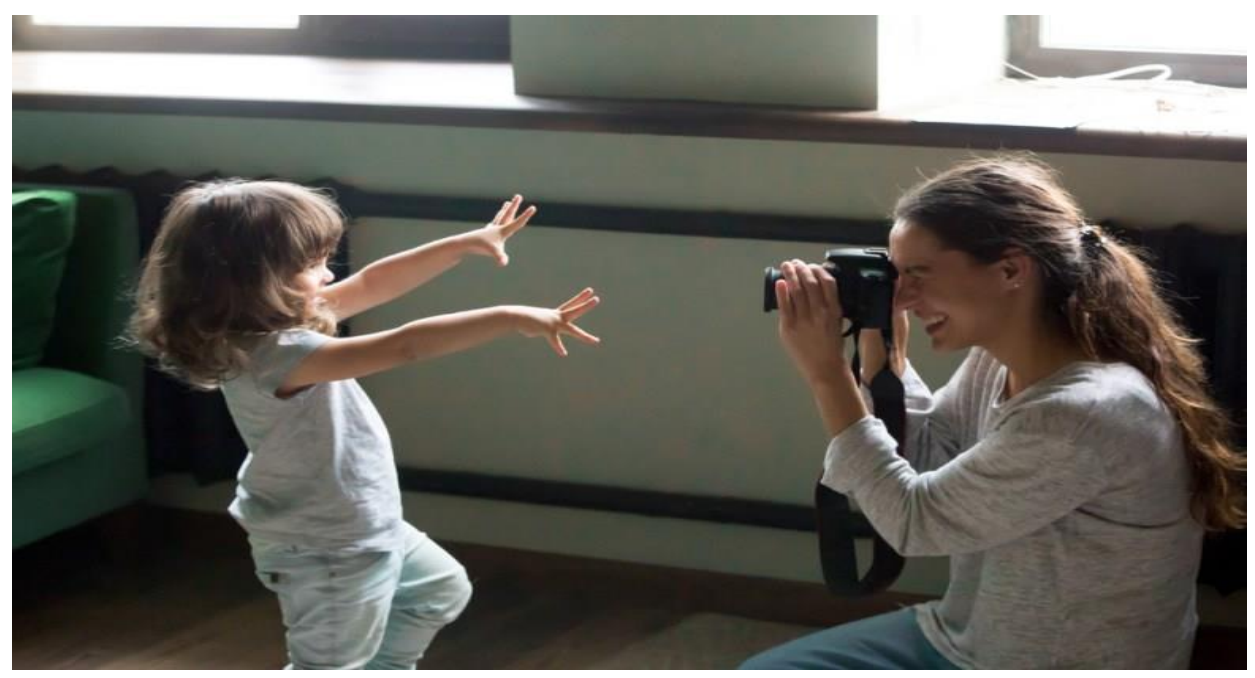

Görsel 1. Sharenting Örneği (Sirapevida, 2021)

Örneğin 1 numaralı görselde yer alan içerikte küçük bir kız çocuğunun annesi tarafindan fotoğrafı çekilmektedir ve bu çekim anı da babası tarafından resmedilerek sosyal medyada paylaşılmaktadır (Sirapevida, 2021). Bu noktaya kadar her şey normalken devreye çocuk istismarcılarının girdiği problemi bir süreç gerçekleşebilmektedir. Bilgisayar ortamında sosyal medyanın bu serbest resim/video paylaşımından yararlanan söz konusu odaklar masum bir resimden photoshop desteğiyle istismar tehlikesi arz eden başka içerikler çıkarabilmektedir. Resmin kırpılarak ikiye bölünmesiyle bu girişim daha kolay sağlanabilmektedir.

Dolayısıyla ebeveynlerin çocuklarına dair paylaşımlar yaparken olası her sorunu düşünmesi gereklidir ve en önemlisi de paylaşımlarını herkese açık bir şekilde yapmamaya 
gayret göstermesidir. Nitekim Youtube, Facebook, Instagram ve Tiktok başta olmak üzere sosyal medyada takipçi/abone elde etmek adına çocukların rızasızca paylaşılan görselleri ve videoları ebeveynlerin görünürlük sağlama çabalarına kurban edilmemelidir.

Lakin sosyal medya üzerinden yoğun kitleleri etkileyen influencer tanımlamalı kişiler, milyonlara ulaşabilmek için bu riskleri dikkate dahi almamaktadır ve sınırsızca resimler, video içerikleri vb. paylaşmaya devam etmektedir. Çocukların hayatını sergileyerek etkileşim elde etmeyi tasarlayan bu yaklaşım, potansiyel zorbalığa ve trollemeye maruz kalınmasını tetiklemektedir. Nihayetinde sharenting eylemi de sosyal medya ebeveynlerinin umursamayıcı bu girişimi sonucunda çoğalmaktadır (Al Kurdi, 2021). Buna rağmen gerek Türkiye'de gerekse küresel dünya genelinde sosyal medyada öne çıkan ve çocuklar üzerinden görünürlük elde eden fenomenler, olası riskleri göze almamakla kalmayıp doğrundan çocuklar adına sosyal medya sayfaları açabilmektedir.

Oysaki ebeveynlerin sosyal medyada sharenting hareketliliğini kontrol etmek adına, paylaşımların ne ölçüde zararlı olduğunu sorgulaması gereklidir. Takipçilerin çocuklara dair her şeyi bilmesi gerektiğini düşünmek ve mutlu bir aile imajına sahip olunduğu gösterme çabası içerisine girmek geçici bir hazdan fazlasını getirmemektedir. Aksine detaylı bilgilere temas eden sharenting eylemleri, çevrimiçi dolandırıcılık ve kimlik hırsızlığı gibi büyük problemlere zemin hazırlayabilmektedir. Zira 2030 yılına kadar sanal ortamlarda icra edilen dolandırıcılık faaliyetleriyle yaklaşık olarak 870 milyon dolar bir kaybın yaşanacağı tahmin edilmektedir (Sirapediva, 2021).

Sharenting içerikli ve milyonlarca takipçisi bulunan çeşitli sosyal medya sayfalarının çalınması ve son yıllarda bilhassa Facebook platformunda gerçekleşen kullanıcı bilgilerinin elde edilmesi gibi öne çıkan problemler, adeta çocukların dijital ikizlerini doğuran bir tehdit meydana getirmektedir. Bugün bu durumun yansımaları gözle görülür boyutta olmasa da hem kimlik bilgileriyle hem de video ve resimleriyle genel profili ele geçirilen çocuklar, farkında olmadan ciddi bir problemin merkezine yerleşebilmektedir. Sorumluluk sahibi olması gereken ebeveynler ise bu meselenin farkına varmak adına çok dikkatli olmalıdır ve çocuklarını sosyal medyanın sorunsalli tarafina teslim etmemelidir.

Çocuklarının doğum anından itibaren mevcut gelişimini kayıt altına alan ve bu safhaları detaylı düzeyde paylaşarak viral hale getiren evrimleşmiş biçimin tehlikesi, sosyal medyada hedef kitlenin giderek yaygin boyuta gelmesiyle kasitlı yahut kasitsız olarak sharenting içeriklerini çocuk avcılarının eline geçirmektedir (Cordeiro, 2021). Kimlik sahtekârlı̆̆ı 
vakalarının \%66'dan fazlasının sosyal medya paylaşımlarından kaynaklandığı ve sharenting eyleminin sahte kimlik elde etme girişimlerine yol açabileceği düşünüldüğünde (Hsu, 2019), bilişim suçlarının ciddi artış göstereceği ayrıca öngörülebilmektedir. Ulusal ve ulusötesi bilişim toplantılarında bu tehlikelere daha fazla atıfta bulunulması ve ebeveynlerin resmi kanallar vasitasıyla uyarılması mühimdir.

Her ne kadar ebeveynler için sanal içerikler paylaşma noktasında uyarı mekanizmaları geliştirilmiş olsa da (La France, 2016), sosyal farkındalık sağlamak açısından girişimler arttırılmalıdır ve kamu spotu reklamları gibi bilinçaltına yerleşecek bilgilendirici adımlar atılmalıdır. Öyle ki çocuklar artık giderek sosyal medyanın metası konumuna gelmektedir ve ebeveynlerin takipçi endeksli para kazanmasının parçası olmaktadır. Bu çerçevede; henüz gerçek hayatı tanımadan sanal hayatta gözlerini açan ve bu ortamı içselleştiren çocukların yaşadığı psikolojik etkiler görmezden gelinmemelidir. Kendi hikâyelerini gerçek hayatta veya şahsi rızaları doğrultusunda sosyal ortamlarda kurgulayan çocuklara izin verilmelidir.

Sosyal medyanın her geçen gün yenilenen ve biçimlenen platformlarında artış gösteren sharenting eylemleriyle, söz konusu kurgulamaya yeterince firsat verilmemektedir ve çocukların özgürlük alanı bizatihi anne ve babaları tarafından elinden alınmaktadır. Bu noktada ayrı bir endişe durumu da devreye girmektedir ve ebeveynler tarafından çocuklar üzerine endekslenen çevrimiçi karakterler, çocukların benlik duygularını geliştirmesini engellemektedir. Böylece kendi hikâyesini şekillendiremeyen ve ebeveynlerinin kurguladığı sanal kimliğe dönüşmek durumunda kalan çocuklar, gerçek hayatı içselleştirememe sorunuyla karşılaşmaktadır (De Marco, 2021).

Yaygın olarak devam eden sharenting eylemini en azından dengeleyebilmek adına harekete geçilmesi de önemlidir ve bu minvalde aşağıda yer alan mevcut faktörlere ebeveynler tarafından önem atfedilmesi mühimdir (Sanghani, 2019):

- Ebeveynler paylaşım yapmaktan geri duramıyorsa eğer, aile ortamında dizayn ettikleri sanal gruplar üzerinden içerik sunmak gibi alternatif ve güvenli yöntemler denemelidir.

- Paylaşım yapılmadan önce bilhassa belirli yaşa gelmiş ve söylenenleri algılayabilen çocuklardan izin istenmelidir ve çocukların da karar verebilen bireyler olduklarının farkına varılmalidir.

- Ebeveynlerin çocuklarına dair paylaşımlar yapmadan önce birbirleriyle görüşmesi de önemlidir ve sharenting eyleminin doğuracağ 1 artılar/eksiler bu etkileşim neticesinde daha net görülebilmelidir. 
- Sosyal medya paylaşımları yapılmadan önce; çocukların da ileride yetişkin bireyler olacağı dikkate alınmalıdır ve gelecekteki benlikleri düşünülerek paylaşılan görsellerden ve videolardan utanç duyabileceği varsayılmalıdır.

- Çocukları mizah malzemesi yapan görseller kullanmak yerine doğum günü pastasıyla poz vermesi gibi tarafsız görseller tercih etmek daha yerinde olacaktır. Ayrıca okul üniformalarını gösteren ve farkında olmadan çocuğun açık adresini teşhir eden tehlikeli paylaşımlardan mutlak düzeyde kaçınılmalıdır.

- Sharenting eyleminden önce sosyal medyanın ne olduğu hakkında çocukların bilgilendirilmesi de önemlidir ve bu bağlamda paylaşımlar yapılmadan önce çocukların fikirlerinin alınması ehemmiyet arz etmektedir.

Diğer taraftan; sharenting eyleminin tehlikeli boyutları ulaşmasının ardından sosyal medyadaki bazı kurumsal yapılar birtakım önlemler almaya başlamaktadır. Örneğin Youtube mecrasında çocukların yer aldığg çeşitli videolar istismar riskine karşı yayından kaldırılmakta ve bu savunmasız grubun pedofillere, çocuk kaçıranlara vb. maruz kalma tehditinin önüne geçilmektedir (Kamenetz, 2019). Çünkü videolarda açık adresleri deşifre edilen ve her detayı paylaşılarak genel profili öne çıkarılan çocuklar farkında dahi olmadan büyük bir problem ile karşı karşıya kalmaktadır. Her ne kadar sosyal medya platformları bu gibi içeriklere müdahale etse de ebeveynlerin de aynı bilince sahip olması elzemdir.

Sharenting eyleminin Instagram boyutu dikkate alındığında ise; bu mecrada genel bağlamda daha fazla içerik paylaşımı yapan ebeveynlerin çocuklarına dair görsel ve videoları bu paralelde daha çok öne çıkardığı olasıllı̆ı öngörülmektedir. Mevcut sosyal medya paylaşımcılığını mahremiyet merceğiyle irdelemeyen ve çocukların gizliliğini ifşa edip servis eden ebeveynlerin bu girişimi, muhtemel sorunları kalıcı kılmaktadır (Ranzini vd, 2020).

Çocukların bu süreçteki tutumu da ayrıca önemlidir ve nitekim sharenting hususunda daha önce yapılan araştırmalarda, çocukların sanal ortamdaki mahremiyetlerine gerçekten önem verdikleri neticesi ortaya çıkmaktadır. Ayrıca çocukların yapılan mevcut paylaşımlara kendilerinin karar vermek istediği ve ebeveynlerinin bilgileri dışında hareket etmesinden asla memnuniyet duymadığı değerlendirilmektedir (Tomchak, 2021). Sharenting eylemine ilişkin Türkiye'de de son yıllarda bilimsel çalışmalar yapılmaktadır ve gerek çocukların gerekse ebeveynlerin görüşleri ölçeğinde bu paylaşım hareketinin artı ve eksileriyle varmış olduğu noktalar sorgulanmaktadır.

Sharenting bağlamında ülke politikaları da artık belirleyici ve caydırıcı olabilmektedir. Örneğin Almanya ve Fransa'da sharenting eyleminin nelere yol açacağına dair kamuoyunu bilinçlendirici politikalar uygulanmaktadır ve olası potansiyel tehlikelere karşı farkındalık oluşturulmaktadır. Bu doğrultuda çocukların yararına olmayan görseller yayınlandığında 
ailelere para cezaları uygulayan katı yasalar devreye girmektedir. Ayrıca medya aracılığıyla bilgilendirici spotlar yapılması zorunlu kılınmaktadır (Hopegood, 2020). Dolayısıyla; Almanya ve Fransa gibi ülkelerin öncü rol üstlendiği bu girişimin küresel dünyada diğer ülkelere de sirayet etmesi ve yayın etki uyandırması sharenting eylemine dair olası riskleri en aza indirgeyebilmektedir.

Çocuğun onurunu ve saygınlığını teşkil eden mahremiyet olgusunu ihlal edebilecek bir yapıya sahip olan sharenting eylemi, çocukları savunmasız bıraktığından ve risklerle karşı karşıya getirdiğinden ötürü (Shmueli, 2011), çocuk ve ebeveyn arasında kalıcı çatışmaya dahi sebebiyet verebilmektedir. Çocuğun psikolojik ve fizyolojik gelişimini riske atan bu durum ebeveynlerin sosyal medya özgürlüğ̈̈ ve çocukların mahremiyet hakkı arasında ayrı bir tartışmayı öne çıkarmaktadır (Cordeiro, 2021). Aşağıda yer alan 2 numaralı görselde yer aldığı gibi, akı1lı telefonlar tarafından kolayca gerçekleşen ve bilinçli yahut habersizce çekilen bir fotoğraf, sharenting eyleminin öznesi olan çocuk ve bu eylemi gerçekleştiren ebeveyn arasında ilerleyen yıllarda fikir çatışmalarına yol açabilmektedir. Bu çatışmaya dur diyebilmek ise, ulusal bağlamda uygulanacak politikalar ve caydırıcı birtakım yaptırımlar ile sağlanabileceği gibi bilinçli ebeveynlik yaklaşımıyla da mümkün görünmektedir.

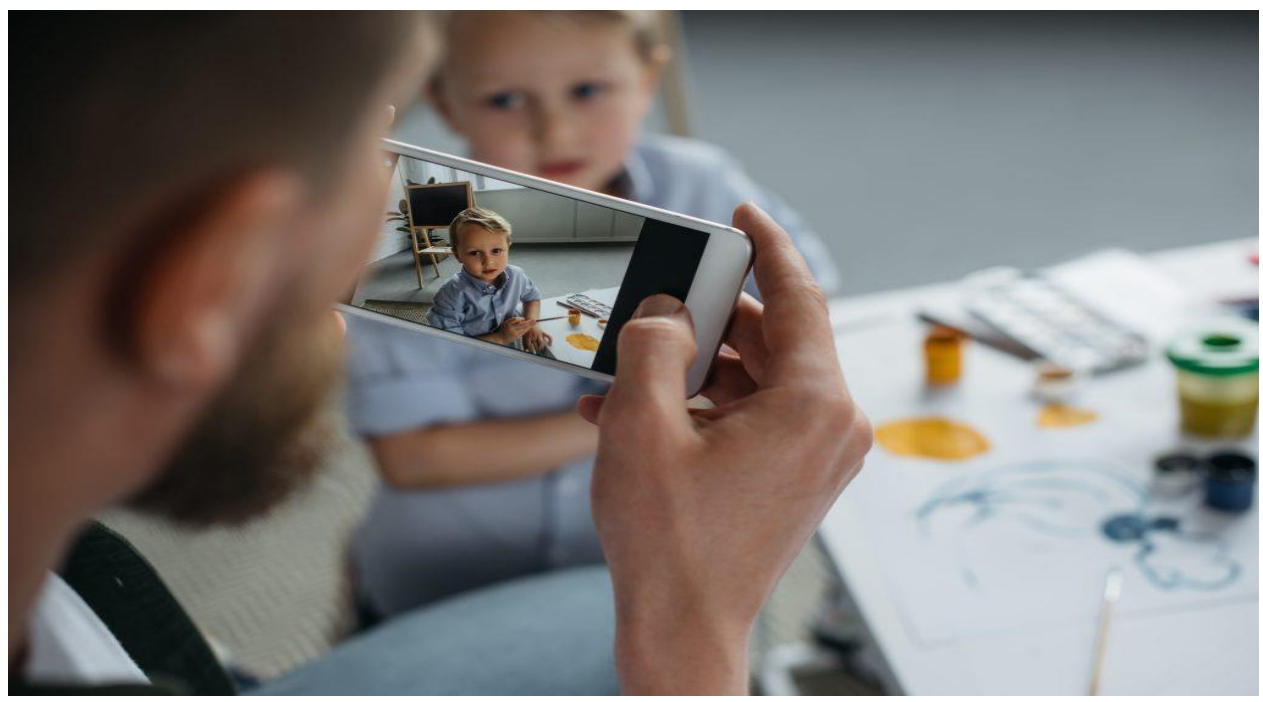

Görsel 2. Sharenting Örneği (Cordeiro, 2021)

\section{Sharenting ve Çocuk İmajı}

Bir çocuğun refahından ve mahremiyetinden sorumlu olan ebeveynlerin çocuğa dair özel ayrıntıları dijital araçlar vasıtasıyla paylaşma girişimi olan sharenting (Hsu, 2019), yeni ebeveynler için ise ilişkileri pekiştirmek ve deneyimler elde etmek bağlamında topluluklara dâhil olma gayesiyle ilişkilendirilmektedir (Bartholomew vd, 2012). Dolayısıyla paylaşımlar 
çocuklara dair anlatılardan ziyade ebeveynlerin anlatılarına katkıda bulunmaktadır ve sosyal medya görünürlüğü sağlamaktadır (Ranzini vd, 2020). Bu görünürlük ebeveynlerin çocuklarını mahremiyet bağlamında koruma güdüsü hissettiği çeşitli uygulamalar eşliğinde de gerçekleşebilmektedir (Autenrieth, 2018). Böylece hem sosyal medyada sharenting eylemini devam ettiren hem de çocuklarını risklerden uzak tutmaya çalışan bir karma yaklaşım söz konusu olabilmektedir.

Ebeveynler tarafından gerçekleştirilen mevcut sosyal medya paylaşımlarının kimi durumlarda olumlu yanları da devreye girebilmektedir ve örneğin engelli çocukların ebeveynleri yapmış oldukları sosyal medya bildirimleriyle etkileşime geçebilmektedir. Böylece ilgili hususta deneyimli olan ebeveynlerin katkısıyla diğer ebeveynler engelli çocuklarını en iyi şekilde nasıl destekleyebileceği hususunda bilgi sahibi olabilmektedir (Meakin, 2013). Nitekim genel bağlamda olumsuz yansımaları olsa da olumlu neticeleri ortaya çıkabilen bir sharenting eylemi icra edilmektedir ve bu girişimle birlikte sosyal medyada yeni bir çocuk modeli inşa edilmektedir. Youtube ve Instagram sayfalarında daha fazla öne çıkan bu model ile birlikte hem engellilik gibi hususlarda farkındalık sağlayan hem de maddi kazancın metası olarak öne çıkan bir profil kurgulanmaktadır.

Örneğin aşağıdaki sosyal medya içeriklerinde; paylaşımları ile Instagram fenomeni haline gelen Şeyma Subaşı'nın ve yine çocuklarının yer aldığı paylaşımlarla takipçi sayısını giderek arttıran Pelin Akil/Anıl Altan çiftinin birer Instagram görseli aktarılmaktadır. Bu paylaşımlarda farklılık teşkil eden husus ise Şeyma Subaşı'nın kızını tatil görsellerinin malzemesi konumuna getirmesiyken Pelin Akil/Anıl Altan çiftinin ise yine kızlarını birçok görselde kullanması ve açık erişimli bu görsellerde ev ortamının ifşa edilmesidir. Her ne kadar Pelin Akil/Anıl Altan çiftinin sharenting eylemlerinde çocuklara dair bilgilendirici videolar yer alsa da mahremiyet sınırlarının aşılması ve çocuklara dair içeriklerin herkese açık olarak sunulması olası tehditlere firsat sunmaktadır. 

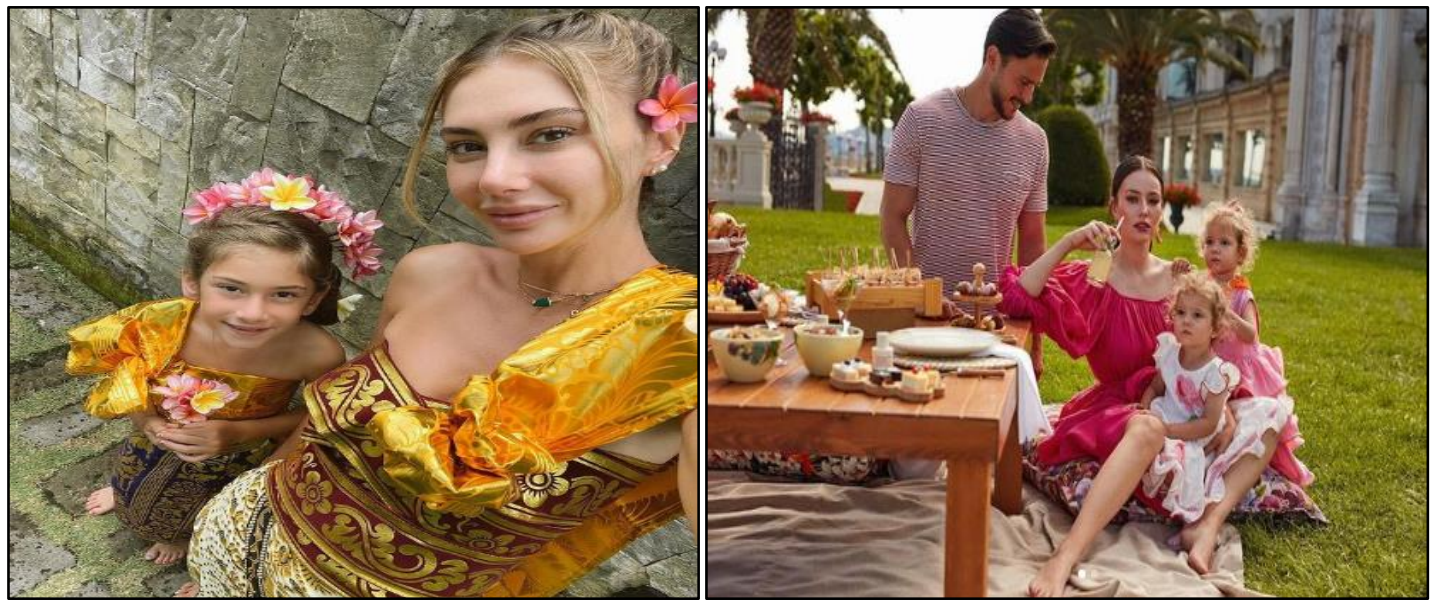

Görsel 3. Sharenting Örnekleri (Instagram, 2021)

Youtube platformunda da sharenting eylemleriyle çocuk imajı inşa edilmektedir ve bu defa abone sayısını arttırma çabasıyla çocuklar maddi kazanç ediniminin metası durumuna gelmektedir. Küçük yaşta Youtube sayfalarında videoları ile öne çıkan çocuklar zamanla bu platformun sanal akışına kendini kaptırmaktadır ve adına açılmış olan sayfalarda bu defa kendileri doğrudan videolar çekebilmektedir. Nihayetinde çocuklarda sanal ortamlara aidiyet hissiyatını oluşturan bir süreç kurgulanmaktadır. Aşağıdaki Youtube görselleri bu durumu örnekleyen içerikler arasındadır ve abone sayısı 10 milyona yaklaşan "Oyuncak Oynuyorum” sayfası ile 3 milyona yakın abone sayısı bulunan "Fatih Selim Tube" sayfası izler kitle tarafindan büyük ilgi görmektedir.
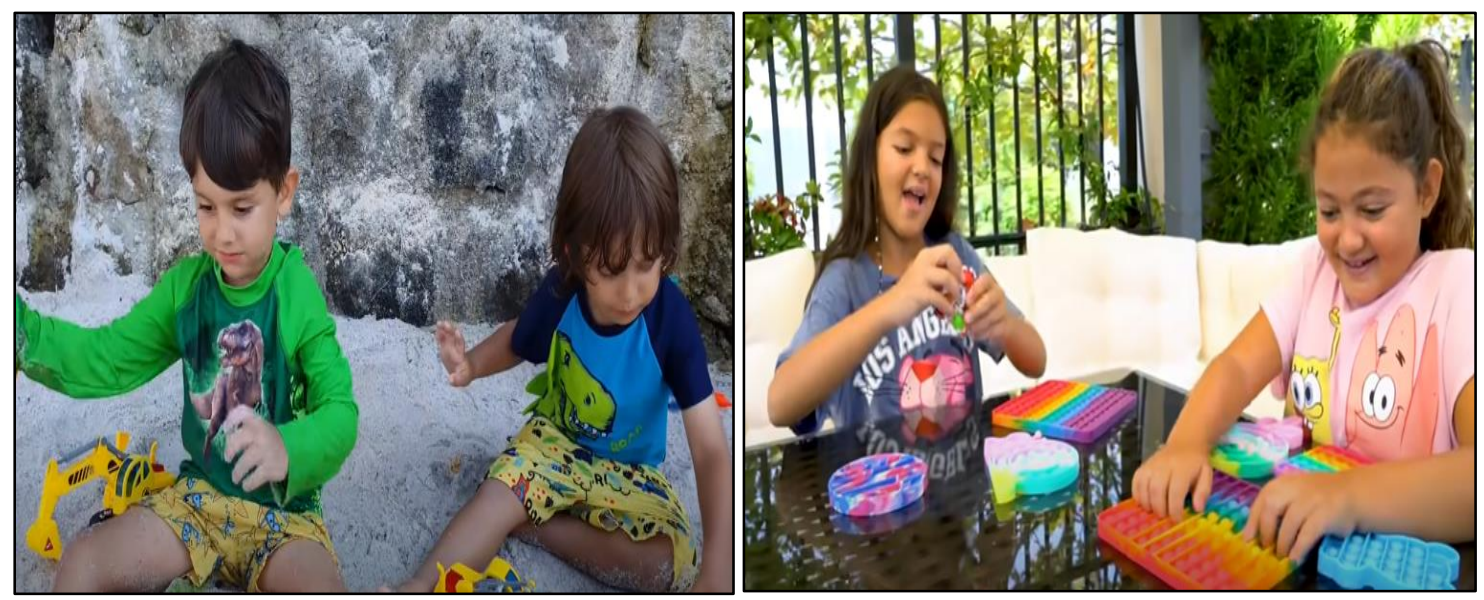

Görsel 4. Sharenting Örnekleri (Youtube, 2021)

Ancak video içeriklerinde okul görüntülerinden tatil içeriklerine, ev ortamlarından arkadaş grupları ile etkileşimlerine kadar her anları paylaşılan çocuklar; sharenting eyleminin olası zararlarına maruz kalabilmektedir. $\mathrm{Bu}$ videolar milyonlarca kez tıklanarak ve beğeni/yorum alarak ebeveynlere önemli kazançlar sağlasa da uzun vadede çocukları psikolojik 
ve sosyolojik düzeyde etki altına alabilmektedir. Sosyal medyada aldığı beğeniler ile her firsatta öne çıkma edinimine giren çocuklar gerçek hayatta bu ilgiyi göremeyince duygusal açıdan da problem yaşayabilmektedir. Sosyal medyanın sharenting ile birlikte inşa ettiği bu çocuk imajı, dolayısıyla birçok açıdan değişkenlik arz edebilmektedir.

Söz konusu çocuk imajı bazı aileleri ise paylaşım yapma noktasında zor durumda bırakmaktadır ve çocuklarının mahremiyeti hususunda tedirginlik yaşayan ebeveynler, görsel ve video paylaşmaları adına çevre baskısı hissetmektedir (Archer ve Kao, 2018). Bununla birlikte çocuklara ise akran baskısı yapılmaktadır ve toplumsal çevre tarafından paylaşım yapılması için tetikleyici rol üstlenilmektedir. Bu karmaşık ortam içerisinde bir taraftan mevcut paylaşımlarının eğlenceli yönü ile ilgilenen ebeveynler, diğer taraftan ise çocukların mahremiyet problemine odaklandığı için gizlilik ve açıklık paradoksuna kapılmaktadır (Chalken ve Anderson, 2017).

Özellikle Instagram sayfaları yeni çocuk imajının kurgulanması bağlamında etkin bir sosyal medya aracı olarak öne çıkarken aynı zamanda ebeveynlerin aileleri ve arkadaşlarıyla topluluk hissiyatı sağlaması duygusunu pekiştirmektedir (Le Moignan vd, 2017). Youtube platformu ise abone sayısı ekseninde daha fazla gelir elde edilen ve ebeveynleri bu yönü ile kendisine çeken bir mecra niteliğiyle kabul görmektedir (Çalış, 2020).

Her yaş grubundan çocukları, rızaları dışında ve ebeveynleri aracılığıyla sosyal medyanın metası konumuna getiren sharenting eyleminin inşa ettiği yeni imaja, aşağıda yer alan şu hususlar özelinde de bakılabilir:

- Sharenting eylemi sosyal medya bağımlısı bir ebeveyn görünümü oluşturduğu gibi çocukları da bu bağımlılığın parçası kılmaktadır ve gerçek hayata adapte olmakta zorlanabilen bir çocuk imajı oluşturmaktadır.

- Sosyal medyada yayınlanan resim ve videolar dijital olarak arşivlendiği ve paylaşım zinciriyle kalıcı hale geldiği için risk durumu da kalıcı olabilmektedir. Bu eksende her daim tehdit altına kalan bir çocuk profili öne çıkmaktadır.

- Ebeveynlerin paylaşım çılgınlığına çocukları da alet etmesi ve başka paylaşımlarda gördüğü içerikleri çocukları üzerinden uygulamaya çalışması, görünürde aktif reel bağlamda ise pasif bir çocuk modeli doğurmaktadır.

- Sharenting ile birlikte oyun çağındaki çocukların dahi rekabet mantı̆̆ıyla yetiştirilmesi, ebeveyn dayatmasıyla psikolojik baskı hisseden çocuk kimliği meydana getirmektedir.

- Sosyal medya mecralarında görünürlüğü fazla olan çocukların yine kendi kararları dışında reklam aracı olarak kullanılması, "ünlü çocuk” tanımlaması elde eden küçük yaş gruplarını ön plana taşımaktadır. 


\subsection{Sharenting Eyleminin Çocuk İmajına Etkileri}

Çalışmanın bu kısmında akademisyen, sosyal medya uzmanı, psikolog ve avukat gözlemleri neticesinde dört ayrı değerlendiremeye yer verilecektir ve ebeveynler tarafindan inşa edilen çocuk imajının nasıl bir görünüm oluşturduğu tartışılacaktır. Bu doğrultuda ilk olarak Doç. Dr. Selda Koydemir'in sharenting eylemi bağlamında öne çıkan çocuk imajına dair aktarımları şu şekildedir (Koydemir, 2018):

Çocuklar ebeveynlerini örnek alır; bu nedenle ebeveynlerin sosyal medya davranışlarının ileride kendilerininkini de etkileme olasılığı büyüktür. Bu şekilde büyüyen çocuklar, gizlilik/mahremiyet gibi kavramlara farklı bir yaklaşım geliştiriyor diyebiliriz. Yani bu ortamda çocukların neyin gizli veya özel, neyin başkalarına açık olduğunu anlaması oldukça zor gibi görünüyor. Bu nedenle bazı sınırlar koyulması, neyi ne kadar paylaşmak gerektiği üstünde biraz daha fazla düşünülmesi önemlidir. Ayrıca çocukların benlikle ilgili farkındalıklarının arttığı, arkadaşlıklarının kurulmaya başladığı 4-5 yaşlarında, onlara kendileriyle ilgili düzenli bilgi paylaşımı yaptı̆̆ınızı anlatmak ve bunu konuşmak, bu yolda atabileceğiniz iyi bir adımdır.

Dolayısıyla çocuklar ebeveynleri tarafindan muhatap olarak alınmalıdır ve sosyal medyada gerçekleştirilen eylemlerin açıklaması anlaşı1ır düzeyde yapılmalıdır. Anne ve babasından gördüğünü uygulama içgüdüsüne sahip çocukların doğru ve yanlışı ayırt edebilmesinin desteği de yine ebeveynler aracılığıyla ayrıca verilmelidir ve sosyal medyadan ziyade gerçek hayat içerisinde etki altında kalan çocuk imajının sağlam temellere dayandırılması sağlanmalıdır.

\footnotetext{
Anne ve babalar, sosyal medyada paylaştıkları fotoğraf ve videoların artık 'internetin malı' olduğunu anlamalıdır. $\mathrm{Bu}$ paylaşımların istemedikleri yerde kullanılabileceğini veya çalınabileceğini de unutmamalıdır. Çocuğu doğar doğmaz, onun dijital kimliğini oluşturan aileler var. En kötüsü de gelecekte neler olacağını bilememeleridir. Çocukların bir birey olduğu unutuluyor. Çocuk, anne ve babanın olsa da onun hakları olduğu bir kenara itilip, onayı olmayan paylaşımlar yapılıyor. Çocukların reyting aracı olarak kullanılması, medya etiği açısından da yanlıştır. İnsanlar özgür olabilirler ama bu, kendi çocuklarının haklarını gasp ederek yapilmamalidır.
}

Sosyal medya uzmanı Esra Öz ise yukarıda yer alan açıklamaları ile sharenting eyleminin sosyal medya boyutuna temas etmiştir ve ebeveynlerin dikkat etmesi gereken hususlara vurgu yapmıştır. Dijital kimlikle bütünleştirilen çocuk imajının aynı zamanda mahremiyet sınırlarını ihlal ettiğini ve sosyal medya etkileşimini arttırmak adına ebeveynlerin bu ihlale yeterince önem atfetmediğini savunan Öz; çocukların haklarına saygı duyulması gerektiğini de belirtmiştir (Kurt, 2017). Olan biteni tam olarak algılamadan sosyal medyada birçok resmi ve videosu dolaşan çocukların ilerleyen yıllarda bu durumdan ötürü aileleri ile ters düşmesi ve sözlü çatışmaya girmesi, kurgulanan çocuk imajının olası neticeleri arasında görülebilmektedir. Nitekim Psikolog Ece Özçıkarak sharenting eyleminin bu yönüne ağırlık vererek tespitlerde bulunmuştur (Tüfekçi, 2021):

Sanal dünyanın giderek daha da yaygınlaşması ile görüyoruz ki birçok ebeveyn, çok küçük olan çocuklarına ve hatta bazen henüz dünyaya gelmemiş bebeklerine bile sosyal medya hesabı 
açarak, paylaşımlar yapmaya başlamıştır. İyi niyetle ve tüm anıların sanal bir platform üzerinde biriktirilmesi amacıyla yapılan bu girişimler, bazen istemediğimiz sonuçlar ile karşılaşmamıza neden olabilir. Öncelikle biliyoruz ki dijital dünyada paylaştığımız herhangi bir içerik mutlaka kayıt altına alınıyor ve biz bu içerikleri kaldırsak da sanal bir hafızada tutulmaya devam ediliyor. Henüz kendi muhakeme yeteneğini kullanamadığı bir dönemde, çocuklarımızın özel fotoğraflarını paylaşmak, başkalarının görmesine izin vermek; ileride çocukların arzu etmediği ve rahatsız olabilecekleri bir durum olabilir. Bu ileride aile ve çocuk arasında sürtüşmelerin yaşanmasına zemin hazırlayabilir. Her ne kadar iyi niyetle yapılan paylaşımlar olsa da henüz kendi kararlarını ifade edemeyen ve yaşı bunun için çok küçük olan bebekler için bu durumun gelecekte bir kişilik hakkı ihlali durumu olarak nitelendirebileceği öngörülmelidir.

Ece Özçırak tarafından çocuk ve ebeveyn arasındaki ilişkilerin sharenting neticesinde varabileceği muhtemel noktaya temas edilirken, bununla birlikte ebeveynlerin yapmış olduğu paylaşımların hukuki boyutuna vurgu yapılmıştır ve kişilik hakkı ihlalinin gerçekleştiği üzerinde durulmuştur. İlgili hususu Avukat Murat Can Pehlivanoğlu ise ayrıca öne çıkararak hak ihlalinin yaptırımlarının olabileceğini bildirmiştir. Zira yetişkin yaşa erişen bireyler, çocukken ebeveynleri tarafından sosyal medyaya servis edilen özel anlarına ilişkin anne ve babalarını dava edebilmektedir. Hukuki anlamda mahremiyeti ihlal edilen çocukları haklı çıkaran bu durum, sharenting eylemlerini sınırsızca devam ettiren ebeveynler için caydırıcı olabilmektedir. Bu minvalde; Murat Can Pehlivanoğlu'nun konuya dair değerlendirmeleri şöyledir (BirGün, 2019):

Bir çocuğun görüntüsünü paylaştığınızda çocuk tacizcileri o çocuğun varlığından haberdar oluyor. Bu gittiği okul olsun, çocuğun yaşadığı çevre olsun, çocuğun nerede bulunduğu yönünde onlara bilgi veriyor. Bu fotoğraflar çocuğun güvenliği konusunda da risk yaratabilir. $\mathrm{Bu}$ doğrultuda kişinin istemediği fotoğrafların paylaşılması kişilik hakkı ihlalidir ve zamanında aileniz size danışmadan fotoğraflarınızı paylaştıysa siz 18 yaşına girdiğiniz anda bu fotoğrafları yayınlayanlara karşı dava açma hakkına sahipsiniz. Ailenin o fotoğrafları kullanarak elde ettikleri gelirleri de onlardan isteme hakkınız olacak. Aile bu karelerden menfaat sağladıysa o menfaate ortak olmak ayrıca söz konusu olabilir.

Netice olarak ebeveynlerin sosyal medya araçları üzerinden sharenting eylemini uygulamaları çocuk imajını doğrudan etkilemektedir ve bu etkinin mahremiyet ölçüsü, hukuki boyutu, psikolojik yansımaları ve tehlike arz eden yönleri bulunmaktadır. Öyle ki yukarıdaki uzman görüşleri söz konusu bu etkileri açıklamaktadır ve her birinde ebeveynler açıkça uyarılmaktadır. Çocuk imajının zedelenmemesi için ise; ebeveynler tarafından paylaşım gizliliğine riayet edilmesi, istismarcıların eline geçebilecek çıplak/yarı çıplak bebek ve çocuk resimlerinin kesinlikle öne çıkarılmaması, konum bilgilerine kolayca erişen sosyal medya platformlarının erişim izni kapatılarak adres bilgilerinin aktarımının engellenmesi gereklidir.

\section{Sonuç ve Tartışma}

Çalışmada literatür verileri ve doküman analizi bağlamında öne çıkan veriler, sharenting eyleminin genel anlamda olumsuz neticeler doğurduğunu göstermektedir. Engellilik, SMA hastalığı, çocuk yetiştirme süreçleri vb. gibi durumlarda her ne kadar ebeveyn paylaşımlarının 
bilgilendirici yönü bulunsa da internet mecrasında cereyan eden tehlikeler ağırlıklı olarak ilgili paylaşımlar üzerinden çocukları tehdit etmektedir. Bu nedenle uzmanlar tarafından ebeveyn bireyler doğrudan uyarılmaktadır ve olası risklerin neler olduğu paylaşılmaktadır. Dünya genelinde bazı ülkelerde ise yönetimsel bazda alından önlemler ve caydırıcı nitelikteki yaptırımlar uyarı mekanizmasını daha hızlı işletmektedir.

Öyle ki paylaşım yapmaktan kendini geri alamayan ebeveynler, bilinçli yahut bilinçsiz olarak çocuklarını sanal tehlikelere açık duruma getirmektedir. İstismarcılar eline geçebilecek bir fotoğrafın nelere sebebiyet vereceğini düşünmeden, sahte kimliklerde yer alan çocuk bilgilerinin ne gibi riskler doğuracağını dikkate almadan yapılan paylaşımlar kalıcı sorunlar meydana getirebilmektedir. Dolayısıyla gerek medya araçları üzerinden kurgulanabilecek kamu spotu bilgilendirmeleriyle gerekse politik minvalde yürürlüğe girebilecek yaptırımlarla ebeveyn paylaşımlarının kontrolü sağlanmalıdır.

Diğer taraftan çocukların da kişilik hakları ve özgür tercihleri olan bireyler olduğu unutulup meta haline dönüştürülmesi ve bu durumun bizzat anne ve babaları tarafından gerçekleştirilmesi, mevcut sharenting probleminin çerçevesini genişletmektedir. Zira ilerleyen yaşlarda bilinç sahibi olacak çocuklar geriye dönüp baktıklarında, sosyal medyada belki de tasvip bile etmeyecekleri şahıslarına ait görsel ve videolarla karşılaşabileceklerdir. Bu durum karşısında utanç duyabilecekleri gibi sanal mecralarda kazanç metası olarak kullanılmalarının hukuki hakları da arayabilecektir.

Çocukların yeni bir model olarak sosyal medyada inşa edilmesiyle ve anne karnından yetişkinlik dönemine kadar özel nitelikteki tüm eylemlerinin paylaşılmasıyla, sosyolojik ve psikolojik çıktılar da mevcut olabilmektedir. Nitekim sharenting ile birlikte sosyal hayattan uzaklaşıp sosyal medya hayatına evrilen ve bu sanal mecrada karşılaştığı sanal ilgiyi her daim bekleyip psikolojik olarak etkilenebilen çocuklar, yaşanan problemli durumdan muzdarip olabilmektedir. Nihayetinde alınması gerek önlemler, uyulması gereken kurallar ve dikkat edilmesi gereken tehditler bulunmaktadır. Çalışmanın içerik safhasında temas edilen ve psikologdan sosyal medya uzmanına, akademisyenden avukata kadar yetkin kişilerin tespitleri ölçeğinde sunulan bilgiler ebeveynler açısından uyarıcı niteliktedir.

Sonuç olarak; sharenting eylemi görünürde basit bir sosyal medya paylaşım hareketi olsa da çocuklar özelinde doğurabileceği sonuçların genel manada olumsuz yönde olduğu anlaşılmaktadır. Aile içerisinde ve yakın arkadaş çevresinde güvenilir düzeyde paylaşımı yapılabilecek video ve resimlerin çeşitli sosyal medya hesaplarında herkese açık olarak öne 
çıkarılmasıyla, olumsuz yansımaların kalıcı olabileceği değerlendirilmektedir. Bu doğrultuda ebeveynler mevcut sorumluluklarını dikkate alarak ve sosyal medya etkileşim hazlarını bir kenara bırakarak çocuklarının mahremiyetini koruma altına almalıdır. Muhtemel tüm riskleri göz önünde bulundurarak hareket etmelidir ve sosyal medyanın yeniden biçimlendirdiği çocuk imajının etkisine kapılmadan masum bir sosyal medya paylaşımın reel göstergeler bağlamında ne gibi neticeler oluşturacağını idrak etmelidir.

\section{Kaynakça}

Al Kurdi, S. (2021). Sharenting: Is It The New Child Abuse? https://www.albawaba.com/business/sharenting-it-new-child-abuse-1439184. Erişim Tarihi: 29.09.2021.

Archer, C. ve Kao, K. (2018). Mother, Baby and Facebook Makes Three: Does Social Media Provide Social Support for New Mothers? Media International Australia, 168(1), 122-139.

Autenrieth, U. (2018). Anti-Sharenting as a Reaction to Risk Assessment and Behaviour Adaption. Digital Parenting: The Challenges for Families in the Digital Age.

Bartholomew, M., Schoppe, S., Glassman, M., Kamp C. ve Sullivan, J. M. (2012). New Parents' Facebook Use at The Transition to Parenthood. Family Relations, 61(3), 455-469.

BirGün (2019). Çocuğunuzun Fotoğraflarını Paylaşırken Suç İşliyor Olabilirsiniz. https://www.birgun.net/haber/cocugunuzun-fotograflarini-paylasirken-suc-isliyor-olabilirsiniz277176. Erişim Tarihi: 27.09.2021.

Blum Ross A. ve Livingstone S. (2017). Sharenting: Parent Blogging, and the Boundaries of The Digital Self. Popular Communication, 15(2), 110-125.

Bowen, G. A. (2009). Document Analysis as a Qualitative Research Method. Qualitative Research Journal, 9(2), 27-40.

Brosch A. (2016). When The Child is Born into The Internet: Sharenting as a Growing Trend Among Parents on Facebook. The New Educational Review, 43(1), 225-236.

Brosch, A. (2018). Sharenting Why Do Parents Violate Their Children's Privacy? The New Educational Review, 54(1), 75-85.

Chalklen, C. ve Anderson, H. (2017). Mothering on Facebook: Exploring the Privacy/Openness Paradox. Social Media Society, 3(2), 1-10.

Cordeiro, V. C. (2021). Children's Rights and Digital Technologies: Children's Privacy in The Age of Social Media. The Perils of Sharenting.

Criscuolo N. (2015). 'Sharenting' Offers Benefits for Parents, Safety Concerns for Children. https://www.wishtv.com/2015/05/06/sharenting-offers-benefits-for-parents-safety-concernsforchildren/. Erişim Tarihi: 30.09.2021.

Çalış, B. (2020). Sosyal Medya Bağımlılığı: Sharenting Nedir? https://blog.adgager.com/sosyal-medyabagimliligi-sharenting-nedir/. Erişim Tarihi: 29.09.2021.

De Marco, M. (2021). "Sharenting" Is a Threat to Children's Health and Personal Development. onezero.medium.com/sharenting-is-a-threat-to-childrens-health-and-personal-developmentbdf2549ec6f. Erişim Tarihi: 28.09.2021. 
Dursun, C. (2019). Ebeveynlerin Çocuklarını Sosyal Medyada Teşhiri: Çocuk Hakları Bağlamında Bir Değerlendirme. Çocuk ve Medeniyet Dergisi, 4(8), 195-208.

Güvenli Web. (2021). Dijital Mahremiyet: Sharenting Riskleri ve Dikkat Edilmesi Gerekenler. https://www.guvenliweb.org.tr/dosya/mtnwT.pdf Erişim Tarihi: 24.09.2021.

Hopegood, R. (2020). The Perils of "Sharenting": The Parents Who Share too much. www.aljazeera.com/features/2020/10/1 1/facing-the-music-the-parents-who-share-too-much. Erişim Tarihi: 28.09.2021.

Hsu, H. (2019). Instagram, Facebook, and The Perils of Sharenting. https://www.newyorker.com/culture/cultural-comment/instagram-facebook-and-the-perils-ofsharenting. Erişim Tarihi: 26.09.2021.

Instagram (2021). https://www.instagram.com/seymasubasi/ Erişim Tarihi: 27.09.2021.

Instagram (2021). https://www.instagram.com/pelinakil/ Erişim Tarihi: 27.09.2021.

Kamenetz, A. (2019). The Problem with "Sharenting" https://www.nytimes.com/2019/06/05/ opinion/children-internet-privacy.html. Erişim Tarihi: 29.09.2021.

Keith B. (2017). Parental Sharing on The Internet Child Privacy in The Age of Social Media and The Pediatrician's Role. JAMA Pediatrics, 171(5), 413-421.

Koydemir, S. (2018). Sharenting Çağında Çocukları Korumak. milliyet.com.tr/ pembenar/doc-dr-seldakoydemir/sharenting-caginda-cocuklari-korumak-2614994. Erişim Tarihi: 25.09.2021.

Kurt, Ö. (2017). Blogger Anneler Teşhirci mi? https://www.hurriyet.com.tr/yazarlar/omur-kurt/bloggeranneler-teshirci-mi-40513007. Erişim Tarihi: 28.09.2021.

La France, A. (2016). The Perils of "Sharenting" All Those Facebook Photos Are Cute - But How are They Affecting The Kids? theatlantic.com/technology/archive/2016/10/babieseverywhere/502757/. Erişim Tarihi: 23.09.2021.

Le Moignan, E., Lawson, S., Rowland, D., Mahoney, J. ve Briggs, P. (2017). Has Instagram Fundamentally Altered The Family Snapshot? Association for Computing Machinery. https://doi.org/10.1145/3025453.3025928 Erişim Tarihi: 28.09.2021.

Meakin, N. (2013)._The Pros and Cons of 'Sharenting'. humanium.org/en/childrens-rights-and-digitaltechnologies-childrens-privacy/. Erişim Tarihi: 26.09.2021.

Morris, M. R. (2014). Social Networking Site Use by Mothers of Young Children. https://doi.org/10.1145/2531602.2531603. Erişim Tarihi: 27.09.2021.

Ranzini, G., Newlands, G. ve Lutz, C. (2020). Sharenting, Peer Influence and Privacy Concerns: A Study on The Instagram-Sharing Behaviors of Parents in the United Kingdom. https://journals.sagepub.com/doi/full/10.1177/2056305120978376. Erişim Tarihi: 28.09.2021.

Sanghani, R. (2019). The Great 'Sharenting' Debate, Are Parents Posting Too Much? https://www.smh.com.au/lifestyle/life-and-relationships/are-parents-infringing-on-children-sboundaries-by-over-sharenting-20191030-p535tt.html. Erişim Tarihi: 26.09.2021.

Shmueli, B. (2011). A. Privacy for Children. Columbia Human Rights Law Review, 42(1).

Steinberg S. (2017). Sharenting: Children's Privacy in The Age of Social Media. Emory Law Journal, 66(1), 839-855. 
Tüfekçi, N. Ç. (2021). Sosyal Medyada Çocuk Paylaşımları ve Sakıncaları. https:// haberveinsan.com/yazarlar/nevzat-caglar-tufekci/sosyal-medyada-cocuk-paylasimlari-vesakincalari/41/. Erişim Tarihi: 25.09.2021.

Wagner A. ve Gasche L. (2018) Sharenting: Making Decisions about Other's Privacy on Social Networking Sites. Multikonferenz Wirtschaftsinformatik Lüneburg. 977-988.

Youtube (2021). youtube.com/channel/UCaGm-DKw5-Ry0nXs2ILIWXQ Erişim Tarihi: 28.09.2021.

Youtube (2021). youtube.com/channel/UCGZrRXxlJGFCH1SMwpMbfAw Erişim Tarihi: 28.09.2021. 